\title{
Medical Student Education Through Flipped Learning and Virtual Rotations in Radiation Oncology During the COVID-19 Pandemic: A Cross Sectional Research
}

\section{Tae Hyung Kim}

Eulji University College of Medicine

Jin Sung Kim

Yonsei University College of Medicine

\section{Hong In Yoon}

Yonsei University College of Medicine

Joongyo Lee

Yonsei University College of Medicine Jason Joon Bock Lee

Samsung Medical Center

\section{Hwa Kyung Byun}

Yonsei University College of Medicine

\section{Yeona Cho}

Yonsei University College of Medicine

\section{Yong Bae Kim}

Yonsei University College of Medicine

Ik Jae Lee

Yonsei University College of Medicine

Kyung Hwan Kim

Yonsei University College of Medicine

Jee suk Chang ( $\square$ changjeesuk@yuhs.ac)

Yonsei University College of Medicine https://orcid.org/0000-0001-7685-3382

\section{Research}

Keywords: COVID-19, Medical Education, Flipped Learning

Posted Date: September 3rd, 2021

DOl: https://doi.org/10.21203/rs.3.rs-847289/v1

License: (a) This work is licensed under a Creative Commons Attribution 4.0 International License. Read Full License 


\section{Abstract}

Background

The COVID-19 pandemic has stripped many medical students worldwide of their right to quality education. In response, we developed hybrid courses involving aspects of both online and in-person teaching for radiation oncology medical student clerkship.

Methods

We entitled students to customize their own rotation schedule using Google Forms and developed a flipped learning online class, which consisted of at least one video clip on basic knowledge of radiation oncology per day (yonsei-radonc.com). Students were instructed to watch online videos before the next day's discussion session. Required components of the medical education program (e.g., target drawing, site visits to treatment facilities) were also prepared and conducted in accordance with the appropriate level of social distancing measures. Finally, we conducted questionnaire surveys after the completion of the week-long course and clerkship.

Results

From March to June 2020, 110 fourth-year medical students undertook a clinical module in our one-week radiation oncology program course. Each day, students completed the flipped learning prior to meeting with the educator and then participated in the online discussion session and conference. All activities were well performed as scheduled. Students' motivation was high, as was their overall satisfaction with the course. The students were satisfied with the online contents, flipped learning strategy, and instructors.

\section{Conclusions}

We successfully integrated open and virtual educational platforms to improve access to and satisfaction with student clerkship. In the future "new normal," minimized face-to-face learning interactions, such as flipped learning, should be actively utilized for medical and other students' education.

\section{Background}

The COVID-19 pandemic has resulted in far-reaching consequences; the closure of classrooms, in particular, necessitated development of alternative methods of delivering education. Professionals in medical education worldwide have explored different methods of modality toward ensuring that students continue to receive quality education.

Flipped learning is a teaching strategy that reverses traditional learning by delivering core content outside of the classroom, and shifts activities more traditionally thought of as homework, into the classroom (Fig. 1) [1]. Lectures have rapidly been developed to be delivered online via platforms such as Zoom, WebEx, and Teams, with such technologically enhanced approaches already being proven to have high levels of engagement with medical students [2]. Amid pandemic-related public health recommendations, education for medical students 
has quickly and effectively transitioned to virtual platforms. In this circumstance, radiation oncology is particularly well positioned to create and innovate virtual curricula for medical students [3].

In response to the COVID-19 crisis, we created a hybrid program comprising virtual and online parts for a oneweek radiation oncology rotation at Yonsei University College of Medicine. Feedback from and the experience of creating and implementing this novel program course will shape the education to be provided in the future. Moreover, the development of virtual education platforms can establish a unique niche within medical education.

\section{Methods}

\section{Students' customized schedule}

According to the academic curriculum of Yonsei University College of Medicine, fourth-year medical students undertake a clinical module in radiation oncology. Our one-week program course included 110 students divided into 16 groups. The course opened on a Sunday evening; students were provided with online links for the flipped learning website and an online questionnaire (Supplementary Fig. 1) that they were instructed to use for creating their own one-week schedule. The online questionnaire had two categories. The first was on the required education curriculum and the second one was on the elective education curriculum that included various categories of available programs. Students had to choose an education location (either "Yonsei Cancer Center" or "Gangnam Severance Hospital"), more than one session in the outpatient clinic of a professor (7 selectable options for professor), more than two multi-disciplinary discussions (7 selectable options), more than one session in a multi-disciplinary team clinic (5 selectable options), and more than two actual radiotherapy sessions (including target/plan confirmation time with a professor, vaginal brachytherapy, and prostate permanent brachytherapy). Students could make their own one-week schedule because they wanted to train in different outpatient clinics, multi-disciplinary team clinics, and actual radiotherapy session according to cancer subtype. Table 1 shows an example of a customized schedule for one student. 
Table 1

Example Schedule for Students

\begin{tabular}{|c|c|c|c|c|c|}
\hline Days & Monday & Tuesday & Wednesday & Thursday & Friday \\
\hline \multirow[t]{2}{*}{$\begin{array}{l}\text { 8:00- } \\
9: 00\end{array}$} & $\begin{array}{l}\text { (R) Introduction } \\
\text { Safety instruction }\end{array}$ & $\begin{array}{l}(\mathrm{R}) \\
\text { Discussion } \\
\text { for lecture }\end{array}$ & $\begin{array}{l}\text { (E) Attend prostate } \\
\text { brachytherapy } \\
\text { operation room }\end{array}$ & $\begin{array}{l}\text { (R) Discussion } \\
\text { for lecture }\end{array}$ & $\begin{array}{l}\text { (E) Attend } \\
\text { multi- } \\
\text { disciplinary } \\
\text { discussion }\end{array}$ \\
\hline & Fellow & Fellow & & Fellow & Professor \\
\hline \multirow[t]{2}{*}{$\begin{array}{l}9: 00- \\
11: 00\end{array}$} & $\begin{array}{l}\text { (E) Outpatient } \\
\text { Clinic }\end{array}$ & $\begin{array}{l}\text { (R) Target } \\
\text { drawing }\end{array}$ & & $\begin{array}{l}\text { (E) Attend } \\
\text { target/plan } \\
\text { confirmation } \\
\text { time }\end{array}$ & $\begin{array}{l}\text { (R) Discussion } \\
\text { for lecture }\end{array}$ \\
\hline & Professor & Fellow & Professor & Professor & Fellow \\
\hline \multirow[t]{2}{*}{$\begin{array}{l}11: 00- \\
13: 00\end{array}$} & $\begin{array}{l}\text { (R) Tour to } \\
\text { treatment room } \\
\text { and simulation } \\
\text { room }\end{array}$ & $\begin{array}{l}\text { (E) Multi- } \\
\text { disciplinary } \\
\text { discussion }\end{array}$ & $\begin{array}{l}\text { (R) Visit carbon-ion } \\
\text { therapy } \\
\text { construction site }\end{array}$ & $\begin{array}{l}\text { (E) Attend } \\
\text { Cervix } \\
\text { brachytherapy }\end{array}$ & $\begin{array}{l}\text { (R) Wrap-up } \\
\text { and discussion }\end{array}$ \\
\hline & Resident & Professor & Resident & Resident/fellow & Professor \\
\hline $\begin{array}{l}13: 00- \\
16: 00\end{array}$ & $\begin{array}{l}\text { (E) Self-study for } \\
\text { next day }\end{array}$ & $\begin{array}{l}\text { (E) Self- } \\
\text { study for } \\
\text { next day }\end{array}$ & $\begin{array}{l}\text { (E) Attend } \\
\text { target/plan } \\
\text { confirmation time }\end{array}$ & $\begin{array}{l}\text { (E) Self-study } \\
\text { for next day }\end{array}$ & \\
\hline & Student & Student & Professor & Student & \\
\hline
\end{tabular}

\section{Flipped learning website}

For the students' flipped learning, we created a website in which core topics on basic knowledge of radiation oncology, as well as basic and advanced techniques in radiotherapy, could be chosen. We uploaded selected lectures delivered in videos lasting 10-20 minutes. We prepared two program courses for each day (total of 10 lectures). Each day of the program was designed to enhance students' understanding of radiation oncology (Table 2). Students were instructed to watch the online videos before the next day's discussion session.

Table 2

Lectures delivered online

\begin{tabular}{|c|c|c|c|c|c|c|}
\hline Days & Sunday & Monday & Tuesday & Wednesday & Thursday & Friday \\
\hline Topic 1 & $\begin{array}{l}\text { Welcome } \\
\text { address }\end{array}$ & $\begin{array}{l}\text { Understanding } \\
\text { RT process }\end{array}$ & $\begin{array}{l}\text { How to target } \\
\text { drawing }\end{array}$ & $\begin{array}{l}\text { Particle } \\
\text { therapy }\end{array}$ & $\begin{array}{l}\text { Intensity- } \\
\text { modulated RT }\end{array}$ & $\begin{array}{l}\text { Future of } \\
\text { radiation } \\
\text { oncology }\end{array}$ \\
\hline Topic 2 & $\begin{array}{l}\text { Introduction } \\
\text { of Yonsei } \\
\text { Rad Onc }\end{array}$ & $\begin{array}{l}\text { Definition of } \\
\text { target and } \\
\text { OAR }\end{array}$ & $\begin{array}{l}\text { Understanding } \\
\text { DVH }\end{array}$ & $\begin{array}{l}\text { Carbon-ion } \\
\text { therapy }\end{array}$ & $\begin{array}{l}\text { Prostate } \\
\text { brachytherapy }\end{array}$ & Wrap-up \\
\hline Instructor & YB Kim & JS Kim & JS Chang & $\begin{array}{l}\text { WS Koom } \\
\& \text { HI Yoon }\end{array}$ & $\begin{array}{l}\text { JH Cho \& YA } \\
\text { Cho }\end{array}$ & $\begin{array}{l}\text { JS } \\
\text { Chang }\end{array}$ \\
\hline
\end{tabular}




\section{Online conferences}

Video conferencing equipment (Logitech Meetup) was installed in a conference room. Before the COVID-19 pandemic, face-to-face internal conferences were held every morning: presentation of new patients (Monday), textbook review by resident (Tuesday), case conference (Wednesday), journal conference (Thursday), and biology/physics lecture (Friday). However, after the COVID-19 outbreak, the morning conferences began to be conducted online, in which students were instructed to participate and strongly encouraged to interact with educators (Fig. 2). The students participated in online conferences via Zoom or offline conferences in accordance with the appropriate social distancing measures. After the internal conferences, students participated in the discussion session with clinical fellows on the topic covered on the previous day.

\section{Required education program}

Required education program components (e.g., target drawing, site visits to carbon-ion treatment facility construction site and treatment rooms at lunchtime) were also prepared and conducted in accordance with the appropriate social distancing measures. A target drawing session was designed for all students with the same patient. Before contouring, the students were taught the concept of hippocampal-sparing whole brain radiotherapy. A 70-year-old male patient with solitary brain metastasis from small cell lung cancer received hippocampal-sparing whole brain radiotherapy. The students contoured the right and left hippocampus, gross tumor on the brain, and whole brain. After contouring, students were shown the actual target drawn by the radiation oncologist and actual radiotherapy plan received by the patient; these were subsequently compared with the students' output.

The construction of a heavy carbon-ion treatment facility at Yonsei University College of Medicine is underway. All students visited the construction site where they attended a lecture on carbon-ion treatment, Bragg Peak of heavy ion, and the advantages and disadvantages of carbon treatment. In addition, all students experienced the operation of the computed tomography (CT) simulation room and linear accelerator and robotic intensity-modulated radiotherapy treatment room. In the CT simulation room, students who wanted to experience actual immobilization during CT simulation and thermoplastic immobilization device (called "Splate") were accommodated as appropriate. In the treatment room, the operation of a treatment machine was demonstrated in the absence of actual patients.

\section{Post-program survey}

At the end of all programs of the academic curriculum, the College of Medicine typically conducts students' surveys on both subject-specific recognition and overall satisfaction, with items being rated on a scale of 1 to 5. The subject-specific recognition survey consists of 12 items. Apart from the university surveys, departments may ask students for feedback. For the present study, online questionnaires prepared by our own department were sent out at the end of each rotation (16 weeks), and each category had either a 1-to-10 scoring system (1 $=$ worst to $10=$ best $)$ or 1 -to- 5 scoring system $(1=$ very poor, $5=$ very good $)$. The categories included the skill and responsiveness of the instructor, quality of the webpage and video lecture, and overall satisfaction with the course content. The survey also included four free-response questions (Supplementary Fig. 2). 


\section{Results}

\section{Overall curriculum progress}

We successfully developed a flipped learning class (yonsei-radonc.com, Fig. 3). All students could utilize the website designed for flipped learning. All activities were performed as scheduled for all students, even with the four-week break imposed after the COVID-19 outbreak.

Figure 4 shows the target volume variation in students' contouring. Most students could delineate brain metastasis well, but showed substantial differences in terms of the contour of the hippocampus and brain structures. We showed the actual target volume used for whole brain radiotherapy to students after their contouring session, and explained the consequences of therapy.

\section{Survey results}

Figure 5 shows the results of the survey conducted by the school. Our department was ranked first among 16 departments in overall satisfaction, and the results showed a gradual improvement in the score in the past years. Table 3 gives the subject-specific recognition results. Although the department had a small number of students in 2016 and 2019, the results indicated gradual improvement. 
Table 3

Survey questionnaire for subjective recognition by school

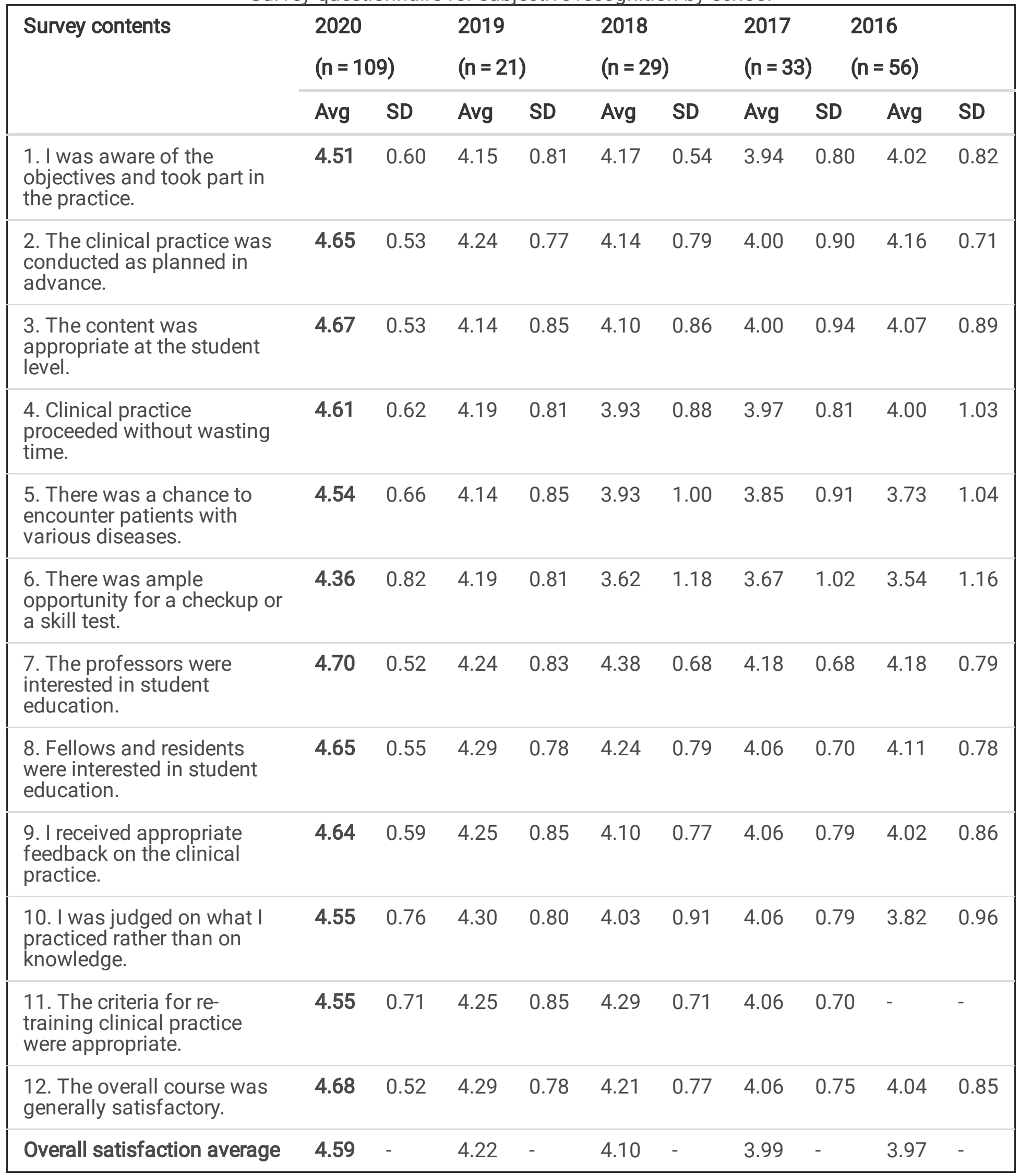

Figure 6 shows the results for the online questionnaire survey conducted by our department. For instructor evaluation, $69 \%, 75 \%, 61 \%, 73 \%$, and $69 \%$ of the students responded "very good" to the items on effectiveness, 
ability to draw interest, time management, availability, and feedback, respectively. For the website and video lecture evaluation, $74 \%, 67 \%, 71 \%$, and $71 \%$ of the students rated as "very good," their effectiveness, ability to draw interest, time management, and availability respectively. The average overall satisfaction score was 9.36 , and $55 \%$ of the students chose 10 (best).

\section{Discussion}

In the present paper, we described the implementation and evaluation of a flipped learning model in an undergraduate medical program. The world has fundamentally changed since the onset of the COVID-19 pandemic in 2020 [4]. In a sense, the pandemic is positively affecting the development of new digital and virtual reality systems. Advances in technology have resulted in a variety of changes in medicine, including in the relationships between patients and doctors, and between teachers and students. Because of the COVID-19 crisis, the traditional mode of education that valued face-to-face interaction, quickly transitioned to a hybrid type that adopted virtual reality (VR) and flipped learning.

Virtual reality, which had been rapidly evolving in the areas of gaming and education, has emerged as an innovative media technology in the medical service software market in conjunction with advances in mobile and display technologies. VR has been applied in education related to surgical instruments, dental techniques using Haptic technology, surgical contents, and experience in the operating room $[5,6]$. Bekelis et al. reported that patients who experienced preoperative VR had increased satisfaction with the surgical procedure [7]. The radiotherapy workflow is a complex multi-step process that is not easily understood by patients and medical students. For this reason, we have conducted and completed the accrual of the prospective randomized study to investigate the clinical usefulness of VR in patients who underwent breast RT (NCT04141943).

Another radical change in medicine is the more frequent application of artificial intelligence (Al) and deep learning (DL). Cancer detection and automatic segmentation using Al and DL are emerging research topics. For example, Xue et al. reported the performance outcomes of 3D convolution network in the detection of brain metastasis [8]; Tang et al. suggested that automatic segmentation using DL could delineate the volume of the brain glioma for radiotherapy [9]. Thus, Al and DL can replace much of what doctors and health care providers used to do.

Education has also been revolutionized by technological advancements. A systematic review of 82 papers concluded that flipped learning is a promising approach to increasing student motivation and engagement; however, the evidence for its effectiveness with respect to knowledge retention and transfer remains lacking [10]. Quantitative and qualitative feedback by students on flipped learning has been highly positive.

Specifically for medical students' education, flipped learning has shown significant improvement in student satisfaction compared with conventional lectures, both in scale scores and free-text feedback [11]. Flipped learning involves not only moving lectures outside the classroom but also proper design that ensures coherence between the face-to-face and online sections of the course. In our program for medical students, we focused on the coherence of the course components. Lessons from the lectures of the day were supplemented by in-person activities, such as site visits or target contouring sessions. 
Nonetheless, flipped learning has some shortcomings. Because of the lack of feedback, some lectures could not accomplish their purpose of providing the appropriate knowledge needed by the student. Students also have fewer interactions with their instructors, who are required to spend a considerable amount of time preparing video lectures. These lectures may also become outdated and require frequent updating, considering the advances in therapy. Thus, instructors will be required to allocate much of their time to prepare and update the lecture videos. Many education specialists insist that face-to-face communication is indispensable in education. However, under special circumstances such as the COVID-19 pandemic, these traditional modes need to be replaced. Innovations in media and technology therefore need to be leveraged to address communication issues.

Our study was limited by the short duration and small sample. However, we intend to use the same program in 2021, and we look forward to be evaluated by the students. We also recognize the non-response bias of the students, which may have had an impact on the feedback results. Another limitation was that the authors were all participants in the delivery of the flipped learning module. Evaluation undertaken by researchers not involved in the delivery may reduce such bias.

\section{Conclusions}

In conclusion, disruption to medical education due to the COVID-19 crisis was avoided with the use of online contents and flipped learning. In the future "new normal," minimized face-to-face interactions, such as flipped learning, may need to be actively utilized for medical and other students' education, to accommodate various needs and circumstances of students.

\section{Abbreviations}

$\mathrm{CT}$, compuated tomography

VR, virtual reality

$\mathrm{Al}$, artificial intelligence

$\mathrm{DL}$, deep learning

\section{Declarations}

\section{Ethics approval and consent to participate}

Not applicable

Consent for publication

Not applicable

\section{Availability of data and material}


The datasets used and/or analyzed during the current study are available from the corresponding author on reasonable request.

\section{Competing Interests}

The authors declare that they have no competing interests.

\section{Funding}

This study was supported by Eulji University in 2021.

This study was supported by the National Research Foundation of Korea (NRF) grant funded by the Korea government (MSIT) (No.2019R1C1C1009359).

\section{Author contributions}

Conceptualization: Kim TH, Cho Y, Kim YB, Lee IJ, Chang JS. Data curation: Kim JS, Yoon HI, Lee J, Lee JJB, Byun HK, Kim KH. Formal analysis: Kim TH. Funding acquisition: Kim TH, Chang JS. Investigation: Kim TH, Chang JS. Methodology: Cho Y, Byun HK, Lee J. Software: Kim YB. Validation: Kim TH, Chang JS.

Visualization: Kim TH, Chang JS. Writing - original draft: Kim TH. Writing - review \& editing: Kim TH, Chang JS.

\section{Acknowledgments}

This study was awarded the 2021 Honorary Prize from Yonsei University College of Medicine for educational excellence in 2020. This study was presented at the Online Conference of The Korean Society for Radiation Oncology on October 10, 2020, and the Online Conference of the Korean Cancer Association on November 12, 2020.

\section{References}

1. Moraros J, Islam A, Yu S, Banow R, Schindelka B. Flipping for success: evaluating the effectiveness of a novel teaching approach in a graduate level setting. BMC Med Educ. 2015;15:27.

2. Kay D, Pasarica M. Using technology to increase student (and faculty satisfaction with) engagement in medical education. Adv Physiol Educ. 2019;43(3):408-13.

3. Kahn JM, Fields EC, Pollom E, Wairiri L, Vapiwala N, Nabavizadeh N, et al. Increasing Medical Student Engagement Through Virtual Rotations in Radiation Oncology. Adv Radiat Oncol. 2021;6(1):100538.

4. https://covid19.who.int/.

5. Brunner I, Skouen JS, Hofstad H, Aßmus J, Becker F, Sanders AM, et al. Virtual Reality Training for Upper Extremity in Subacute Stroke (VIRTUES): A multicenter RCT. Neurology. 2017;89(24):2413-21.

6. Ganry L, Hersant B, Sidahmed-Mezi M, Dhonneur G, Meningaud JP. Using virtual reality to control preoperative anxiety in ambulatory surgery patients: A pilot study in maxillofacial and plastic surgery. $J$ Stomatol Oral Maxillofac Surg. 2018;119(4):257-61. 
7. Bekelis K, Calnan D, Simmons N, MacKenzie TA, Kakoulides G. Effect of an Immersive Preoperative Virtual Reality Experience on Patient Reported Outcomes: A Randomized Controlled Trial. Ann Surg. 2017;265(6):1068-73.

8. Xue J, Wang B, Ming Y, Liu X, Jiang Z, Wang C, et al. Deep learning-based detection and segmentationassisted management of brain metastases. Neuro Oncol. 2020;22(4):505-14.

9. Tang F, Liang S, Zhong T, Huang X, Deng X, Zhang Y, et al. Postoperative glioma segmentation in CT image using deep feature fusion model guided by multi-sequence MRIs. Eur Radiol. 2020;30(2):823-32.

10. Chen F, Lui AM, Martinelli SM. A systematic review of the effectiveness of flipped classrooms in medical education. Med Educ. 2017;51(6):585-97.

11. Chowdhury TA, Khan H, Druce MR, Drake WM, Rajakariar R, Thuraisingham R, et al. Flipped learning: Turning medical education upside down. Future Healthc J. 2019;6(3):192-5.

\section{Figures}




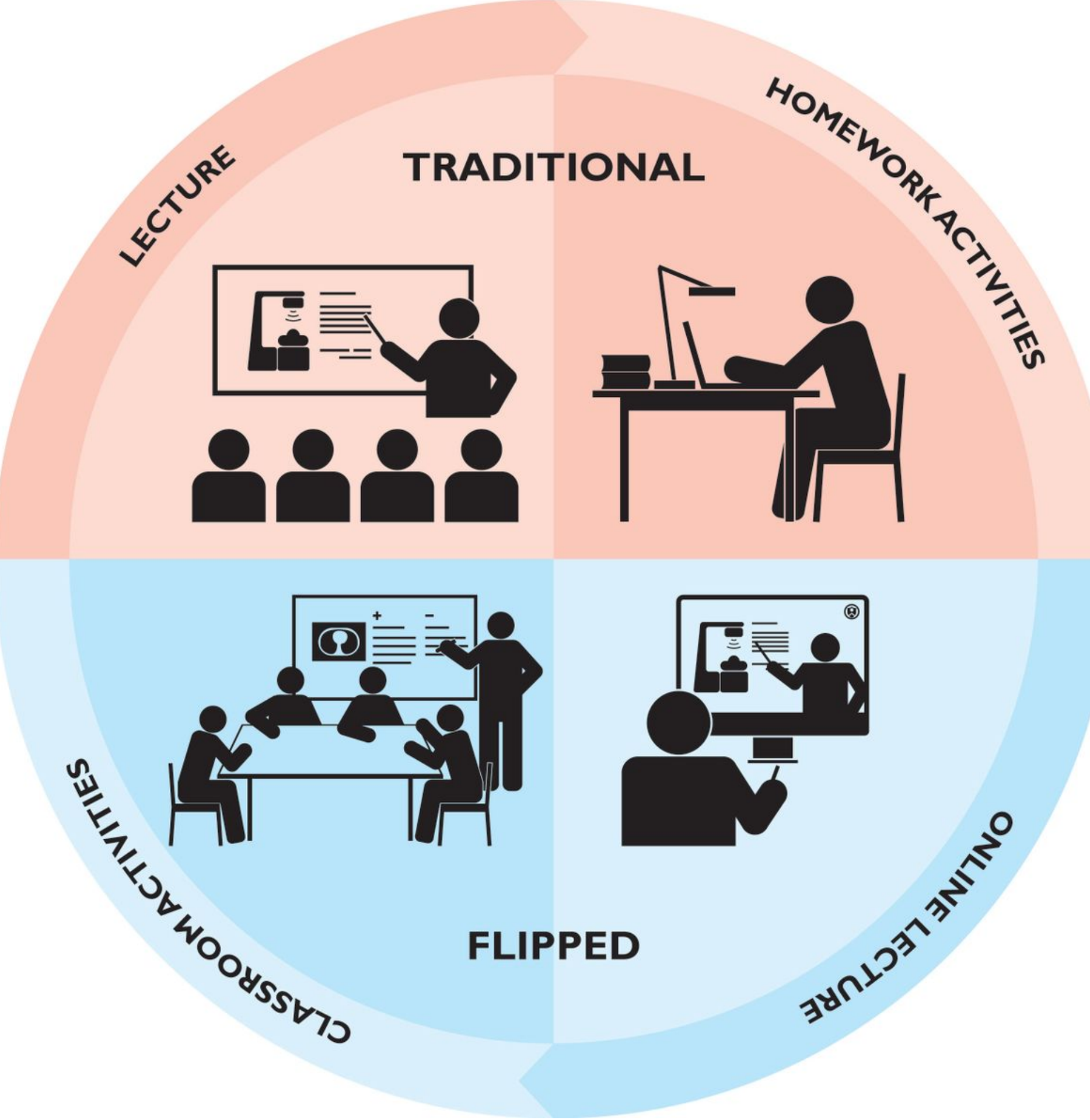

Figure 1

Flipped learning versus traditional learning. Note: The upper row shows traditional learning consisting of lectures conducted in person and homework activity. The lower row shows flipped learning consisting of lectures conducted online and classroom activities. 


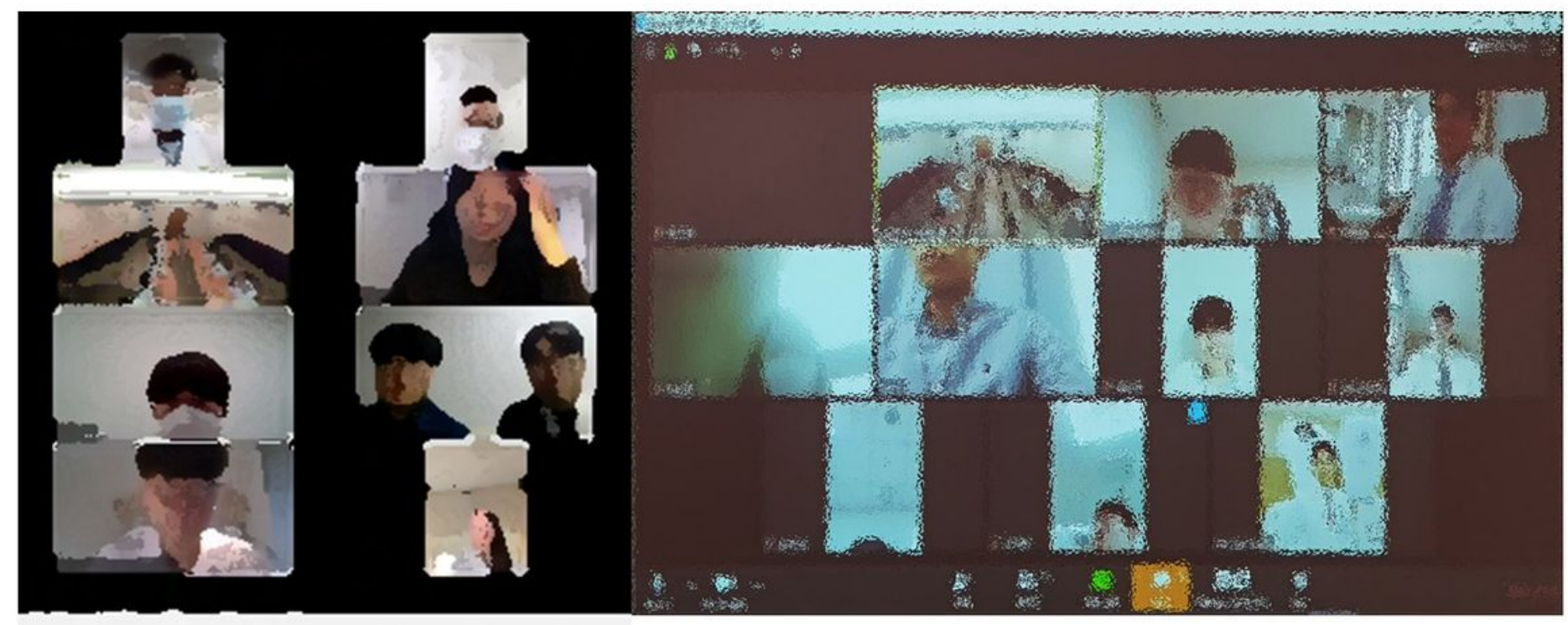

Figure 2

Internal conferences conducted online 


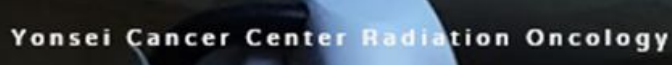 \\ 연세암병원방사선 종양학과}

이사이트는 학생 교육을 위하여 연세 암병원 방사선 종양학과에서 운영하는 홈페이지입니다.

Information contained within this web site is intended solely for educational purposes only for Yonsei students

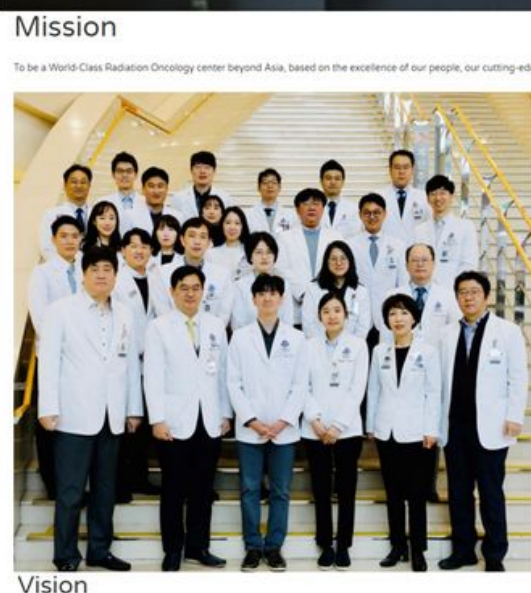

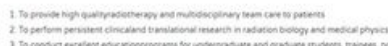

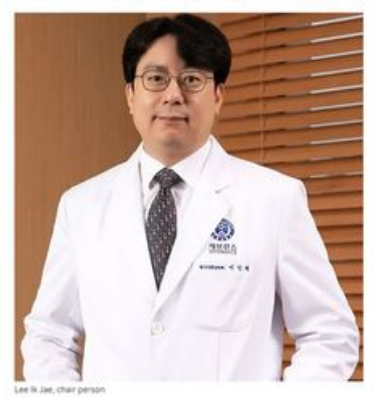

Figure 3

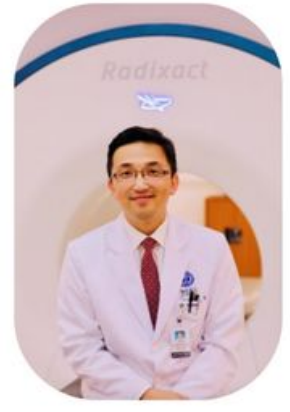

\section{강의자: 김진성}

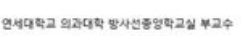

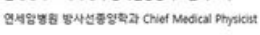

학습 육표: 방사선 치료의 과정 및 용어를 이해한다.

Contents

1. 암 관련 통계

2. 방사선 치료의 역사

3. 방사선 치료 과정 (08:00 )

출처: 미스터염피 채널

강의자: 장지석 조교수

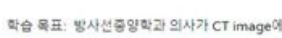
target과 OAR을 그리는 과정과 개넘을 이하현대
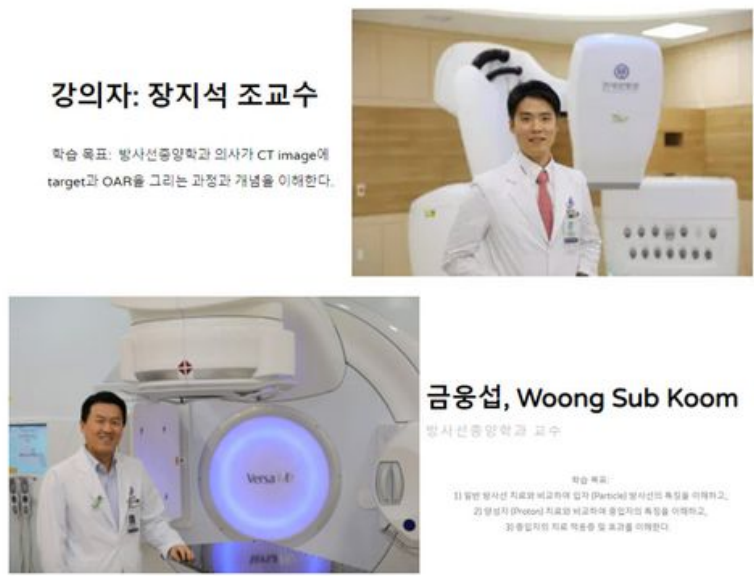

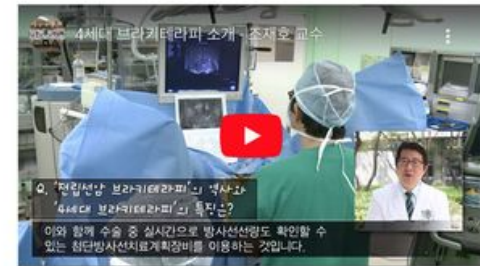

Prostate brachytherapy는 무엿인가요?

브라키세라피의 역사, 4세대 브라키테라피의 특징은 무엇인지 알아보지 조재호, Jaeho Cho

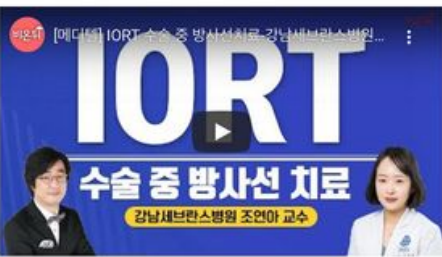

Intraoperative RT (IORT)는 수슬 중 시행하는 치료법으로 국내이서는 강낭세브련스병뭔이 최초로 시행.

2014년 유방암 수술중 첫 시형 이후 2019년 8월 500례 돌파. 유방앙에 이어 대장암, 셰장암 등 IORT 적용범위를 왁대.

조연아, Yeona Cho

Flipped learning class (yonsei-radonc.com) 


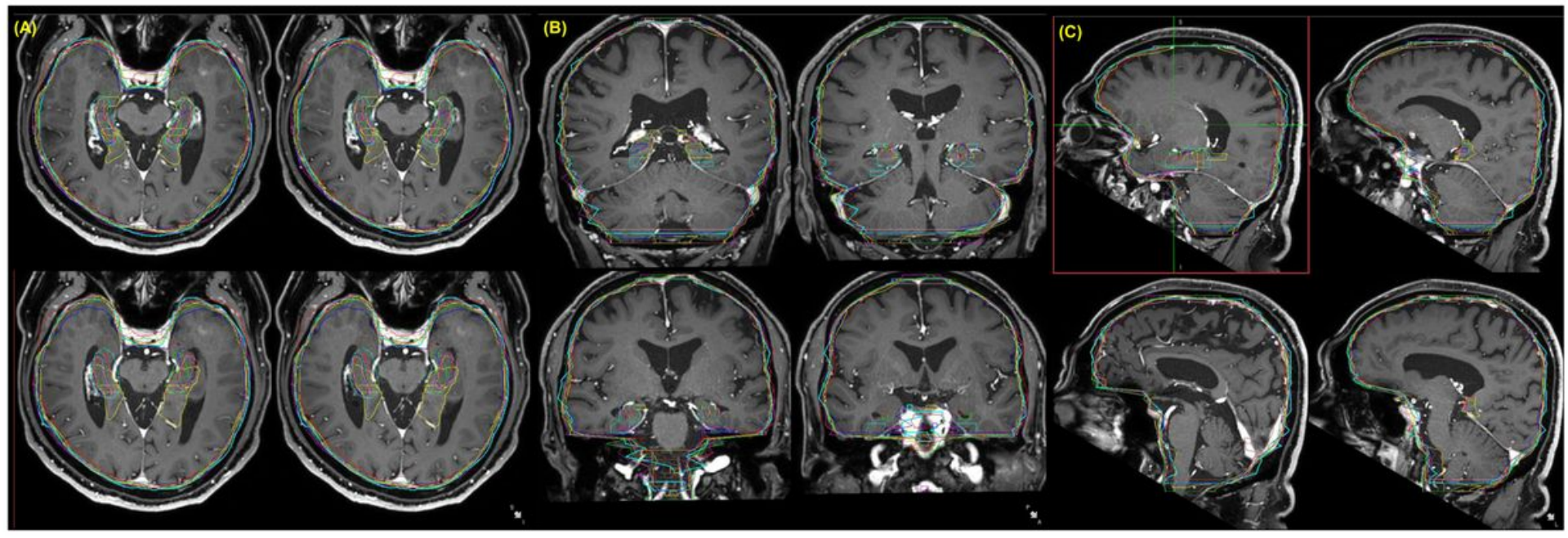

Figure 4

Target volume variation in students' contouring 
5.0

4.8

4.6

4.4

4.2

4.0

3.8

3.6

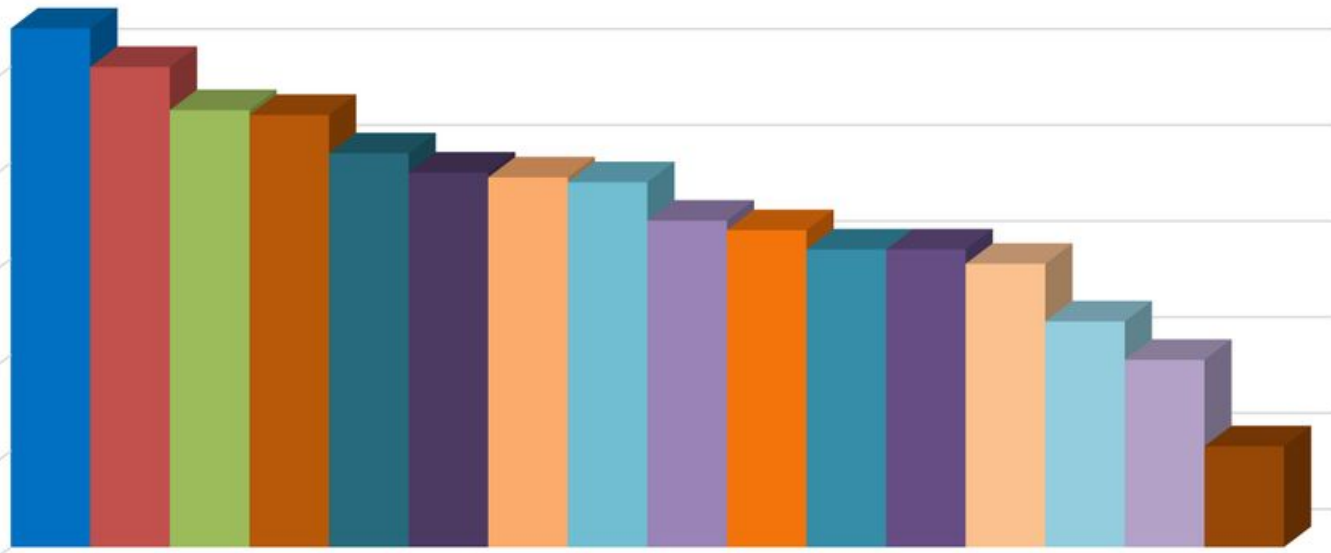

RO

\section{Score}

5.0

4.9

4.8

4.7

4.6

4.5

4.4

4.3

4.2

4.1

4.0

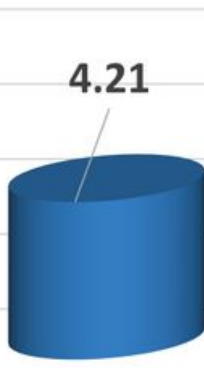

2018
4.29

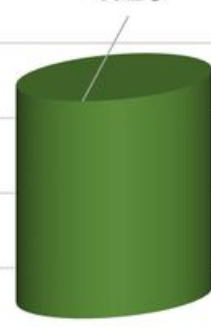

2019

4.68

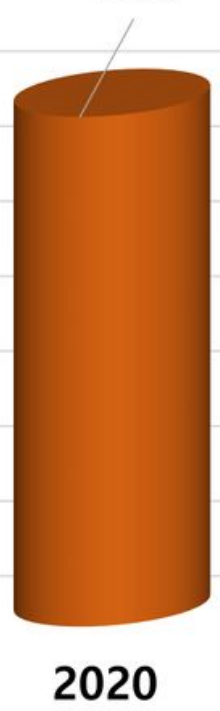

\section{Figure 5}

Survey results by school. (A) Overall satisfaction score in 16 departments. (B) Score changes for radiation oncology over three years 

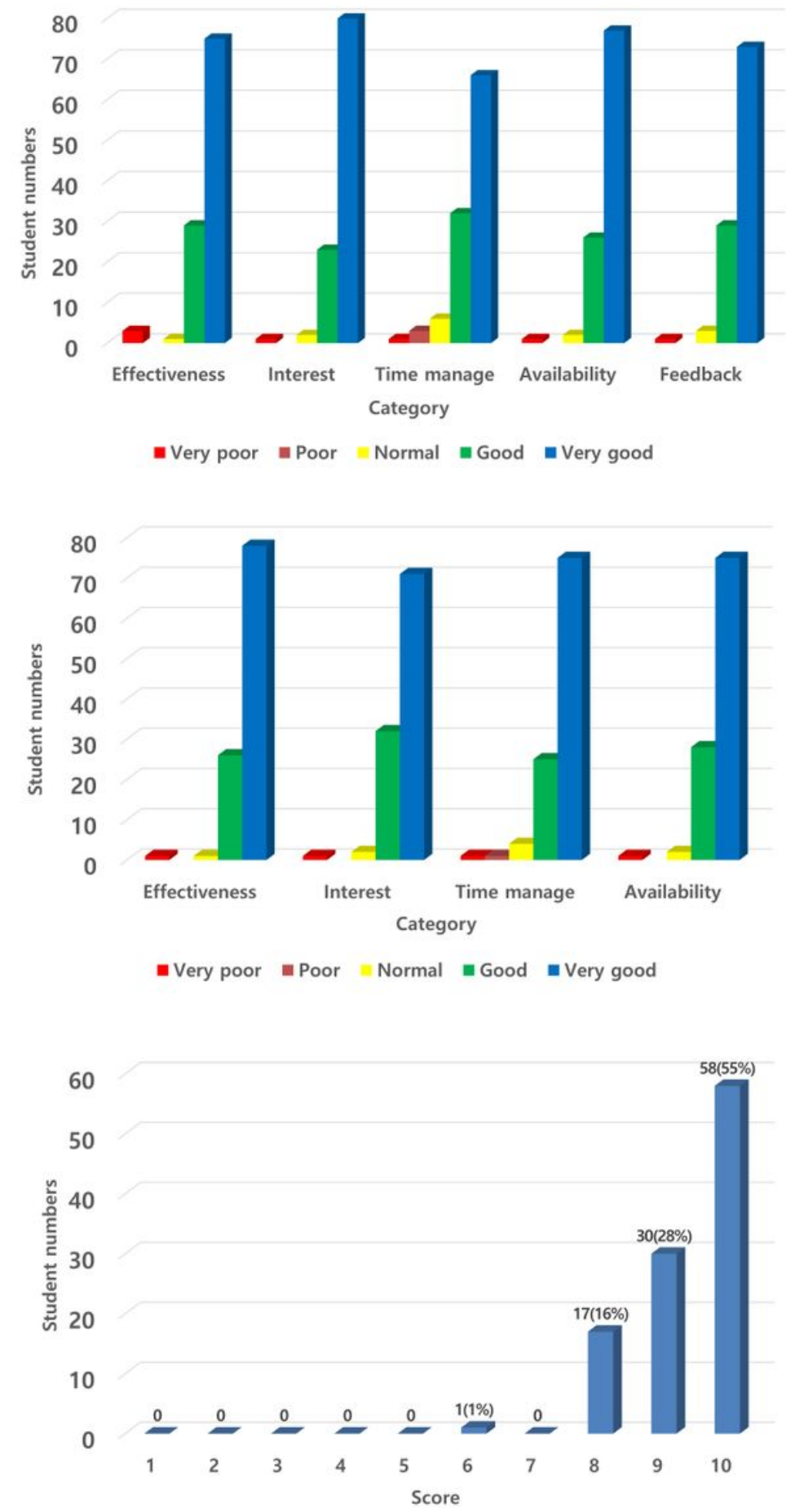

Figure 6

Results of the online survey by our own department. (A) Instructor evaluation. (B) Website and video lecture evaluation. (C) Overall satisfaction Supplementary Figure 1. Online questionnaire for students' customized schedule Supplementary Figure 2. Online questionnaire for post-program survey

\section{Supplementary Files}

This is a list of supplementary files associated with this preprint. Click to download. 
- SuppleFigure1.tif

- SuppleFigure2.tif

Page 18/18 